\title{
Editorial
}

\section{In the shadow of Paris: theories of justice and principles of harm}

With the Paris Conference of the Parties to the UN Framework Convention on Climate Change due to get underway as this edition goes to press, we cannot yet know how the surging call for 'climate justice' will have been advanced by the time you read this - if at all. What is clear, and likely to remain so, however, is that the work of meeting the inexorable demands of those dispossessed by climate change, and those in the anteroom of dispossession, has barely begun. This edition of the Journal of Human Rights and the Environment features a rich range of analysis, theoretical inquiry and practical suggestion that will prove of immense help, perhaps most especially once the clamour of climate justice demands reaches a pitch that can no longer be ignored. The edition places climate justice in the context of the broader terrain of 'environmental justice' and human rights, and publishes the views of a select group of scholars addressing both the big picture and the policy detail.

Setting the scene, Upendra Baxi canvasses a family of ideas characteristic of contemporary justice concerns. He identifies these as three 'theories' - of global justice, environmental justice and climate justice respectively.

Locating 'global justice' largely within the recent surging cosmopolitan literature (though he distinguishes utilitarian and deontological strains in passing), Baxi notes that the principal concern in these theories is neither with inter-state settlement of conflict, nor with intra-state distributive justice, but with cross-border distributive dilemmas. Human rights feature in contemporary global justice accounts, but not primarily Baxi perceptively observes - by reference to international human rights law; instead it is the 'moral idea of human rights' that animates these theorists. And yet, while divided on which particular justice questions ought to be foregrounded, theorists of global justice are apparently united, he notes, in their 'determination to keep the number and nature of moral rights as human rights to as few as possible'. For Baxi, the rise of the Anthropocene 'aggravates the tasks of global distributive justice', making it increasingly difficult to ignore not only the striking injustice of the incoming climatic ordering, but also raising the stakes for older calls for redress - for the wrongs of 'colonization and imperialism of the Westphalian, and contemporary, Cold War and war on "terror" eras'. Climate justice - in its first oblique appearance here - is suffused with the claim of the past on the present.

For Baxi, 'environmental justice' involves the recognition of environmental 'problems' - waste, pollution, ecosystem degradation - as affecting socially vulnerable and marginalized persons and peoples in particular, and of the role of racism in allocating the burdens of environmental damage. This still recent tradition has added 'to the notion of justice also that of fair and equal participation of the impoverished and the indigenous peoples and concepts of fair procedural justice'. Baxi mentions in passing the cognate notion of sustainable development, suggesting that it is 'more a matter of policies of governance ... than an agendum of justice'. Crucially, however, he insists that environmental justice must always co-exist with the axiom 
that there is 'no development without destruction', that some degree of development is not only 'inevitable but ... also just', and that therefore, that "some "moral loss" is always entailed when we [enter] the secular theologies of "development", "free markets", or "post-development". The question for environmental justice, then, is where to draw the line: 'Is moral loss always to be borne as the costs of development by the communities of the worst-off in all societies?'

Turning properly, then, to 'climate justice', and citing Stephen Gardiner, Baxi proposes that climate change presents a 'perfect moral storm', in which 'even if the difficult ethical questions could be answered, we might still find it difficult to act. For the storm makes us extremely vulnerable to moral corruption'. Theories of climate justice must deal with the existing set of global and environmental justice concerns and add to these complexities of climate responsibilities and burden-sharing. Existing justice principles cannot yet achieve 'the political urgency that global climate change ... summons'. In the meantime, '[t] he overarching factor and context now is to discover new ways of building our concerns with human well-being, capabilities and flourishing in ways that enhance species survival'. Again and again, Baxi returns to principles of harm - and to 'no harm' principles. 'Never before', he mourns, 'was the imperative to relate theory to practice felt to be so pressing'.

Baxi's is a royal road through numerous complex theories of justice and human rights, and few of the lay-bys are left unexplored. However, he pulls the reins at the cusp of the Anthropocene. Climate justice ought to avoid anthropomorphism, he observes. And yet it is not at all clear how this should be done. Where should the line be drawn? Some form of 'planetary loyalty'? Or should our 'care' extend to 'the normative protection of all lifeforms and lifeworlds on planet Earth - and life wherever found in other galaxies'? Of course, no such ethics exists. This may be the inherent drawback of the Anthropocene as a frame: once we have drawn our gaze back to the geologic, how are we supposed to maintain any ethics at all? Even if we restrict our gaze to 'all of humanity' we are immediately faced with the fact that human rights do not - cannot - end with the lengthy list of the lex lata. There is always also a background human right, the meta-ethical right, to do 'moral wrong', as Baxi puts. 'In a capitalist and market society and economy, where exploitation is the rule and emancipation a utopia, the human right to a free competition signifies a right to cause harm to innocent and vulnerable others'. There is no escaping harm, it seems. Whose rights, then, prevail, and against whom? Baxi abstracts the question by turning his gaze to the 'infinity' of future generations, to whom an exponentially growing burden is passed from one generation to the next. 'Is an infinite justice obligation any ethical obligation at all?' Baxi's contribution exceeds the terms 'rich' and 'fertile' - and throughout his analysis he is faithful to the maxim he introduces at the close: 'Thinking about climate change justice requires "epistemic insubordination", not semiotic enchantment - or worse still "semiotic enslavement".

Anchored, by contrast, in a concrete policy question, in 'Climate justice, loss and damage and compensation for small island developing states' (SIDS), Sam Adelman responds to the particular vulnerability characterizing communities living on low-lying islands at risk of inundation by the sea. He argues in support of no-liability compensation for climate loss and harm for such communities, arguing that such compensation could take the form of resettlement or of monetary compensation. Adelman develops his argument by focusing on the need for a relatively straightforward, just and operationally efficient response to the particular vulnerabilities, harms and losses faced by such island communities. He points out that loss and damage from climate change will inflict intolerable physical, social and psychological harms on SIDS - and that these cannot be 
adequately addressed through adaptation and mitigation policies, nor by aid, private or social insurance or payments from adaptation funds. The need for compensation is, moreover, a question of climate justice: SIDS bear the brunt of the climate impacts caused by more developed countries - a disparity justifying the claim that developed countries 'are ethically obliged to compensate SIDS for climatic loss and damage'. Moreover, Adelman suggests this 'obligation can be discharged through compensation without admission of liability'. This approach avoids some of the more complex and slippery questions around the embrace of liability rules (traditionally thought not to apply to climate change because the number of victims (and tortfeasors) was 'potentially infinite'), while simultaneously focusing on recuperation. Recuperation, for Adelman, is a goal fully justified by the lack of choice forced upon SIDS due to their exposure to intolerable levels of climate risk. Adelman builds his case by combining climate justice principles, corrective justice, a consideration of the application of the no-harm rule in international environmental law, an analysis of the plight of islanders forced to relocate and resettle without the protection of international law, and an analysis of the Warsaw Mechanism and arguments for compensation.

The Warsaw Mechanism currently presents an invidious Catch-22 for SIDS: it is focused 'primarily on insurance rather than compensation at the behest of developed countries [meaning] SIDS face the paradox that insurance depends upon risk reduction through adaptation measures for which they have inadequate resources'. The injustice here is apparent, and Adelman's argument that compensation for loss and damage presents an ethically satisfying and viable approach to climate justice promotion seems difficult to resist - especially when placed against the longstanding structural imbalances characterizing the genesis, development and material practices of climate injustice. 'The demands of climate justice require international protection for people forcibly displaced by climate change and compensation for the physical, psychological and cultural harms that result. Climate justice should not be a matter of benevolence or humanitarian assistance but, in the form of compensation, a way for developed countries to discharge their ecological debts', argues Adelman. It is difficult to disagree. Indeed, as Adelman himself remarks in his parting comment, 'Given the scale of climate change and the urgent need to address it, compensation is hardly a radical demand'.

Silja Klepp and Johannes Herbeck also focus on small island states, this time with a view to advancing discussion on climate migration, an issue which - as is too well known - has long seemed blocked within the international institutions mandated to tackle it. As the authors point out, the mainstream debate has moved in a counterintuitive direction - on one hand, de-emphasizing the whole notion of a climatemigration link (preferring to focus on the complexity of inter-related factors necessary to trigger the mass mobilization of populations), and, on the other, rearticulating migration as a legitimate adaptation response (as though climate change were merely a 'natural' phenomenon). The pre-emptive move appears to be to reframe climate migration as a primarily national or regional problem, which, Klepp and Herbeck point out, tends to reinforce 'racialized imaginative geographies that run counter to attempts to connect the debate to climate justice considerations'. The 'anti-politics machine' of western development co-operation works to obscure 'questions of regional and global responsibility and solidarity, as well as historical and current power relationships and dependencies'. At the same time, they note, 'oversimplified accounts of the connections between environmental change and migration are a significant part of a broader securitization discourse that depicts climate change as an increasing threat to national security'. In consequence, climate migration policy 
is 'characterized by ad-hoc solutions ... rather than by the development of a global solution'.

In contrast to all this, Klepp and Herbeck describe the negotiations that have been underway among a number of South Pacific islands aiming to respond pragmatically to the extraordinary challenges already being felt in the region while remaining sensitive both to the complexity of actual circumstances and to broader notions of justice. Migration debates in Kiribati and Fiji, extending to the renegotiation of existing arrangements with New Zealand, are concerned with 'concrete, local, social and connective questions around climate justice', resisting a collapse into developmental and security nostrums. The authors wish to show how the 'language of justice [can] work not only as a neutral medium in societal debates but also as a "technology of power" capable of moving debate forward if applied at the right moment. Klepp and Herbeck propose that the debates on the environmental-migrant nexus in these islands 'inaugurate [a] more connective, post-colonial response' that can repoliticize migration discourse globally.

Klepp and Herbeck's research has an empirical dimension, in so far as they base some of their conclusions on interviews undertaken with negotiators from the islands concerned, Kiribati and Fiji. Christopher Jeffords, in his article in this issue, also takes an empirical approach to the relationship between the existence of constitutional environmental rights (in legislative or constitutional form) and the actual improvement of human rights (in this case, the right to water), in practice.

Contributing to a nascent literature quantitatively examining the relationships between constitutional environmental rights (CER) provisions and environmental outcomes, the primary aim of Jeffords' analysis is to test 'whether or not the presence of CER provisions, and the subsequent number of language categories, have any effect on the access to sanitation and water measures'.

According to Jeffords, 125 countries now have environmental rights provisions of some sort, while the numbers for those lacking access to 'improved drinking water' have been falling precipitously, with 2.3 billion people gaining access between 1990 and 2012. To what extent is the latter due to the former? Controlling for the length of time during which a provision has been in force, Jeffords finds a positive, statistically significant, association between older environmental rights provisions and access to improved water sources. However, no such association is found for access to improved sanitation (also an element of the right to water), with 2.5 billion people in developing countries still deprived. Jeffords' analysis points up an intriguing difference between countries with British (ie, common law) colonial backgrounds and those with French legal origins. It seems that while countries with French legal origins are more likely to include broader economic and social rights in their constitutions, former British colonies that constitutionalize environmental rights are more likely to put them to use. This distinction between these two omnipresent juridical cultures opens a space for further research to 'uncover the reasons why legal origins matter for environmental outcomes, specifically through constitutional avenues'.

Moving from the Pacific to Europe, and from empiricism to critical analysis, Kristian Cedervall Lauta and Jens Elo Rytter's article 'A landslide on a mudslide?' explores several threads linking injustice, justice, human responsibility and environmental harm - specifically, in this case, environmental 'disaster'. In the course of his astonishing peregrinations, Upendra Baxi had raised Judith Shklar's famous distinction between 'natural' and 'man-made' disasters, where the first is a misfortune, the second an injustice. Shklar had already noticed - Baxi points out - that, in practice the distinction does not hold terribly well, since governments may also find themselves 
responsible for failure to prepare for natural disasters when they have the information and wherewithal to do so - turning a misfortune into an injustice. Baxi observes that the distinction further collapses in the era of climate change, as 'natural' disasters turn out to have anthropogenic causes. Lauta and Rytter examine this point in detail, focusing on the recent jurisprudence of the European Court of Human Rights for evidence that the old distinction between 'natural' and 'man-made' disasters might also be blurring at the Court. While the Court has well-established case law finding state responsibility for human rights violations in cases of man-made, or industrial, disasters (a well-known example being the 2004 case Önerylldz $v$ Turkey), it was only in 2008, with the case of Budayeva v Russia, that the Court extended this jurisprudence to non-man-made disasters, in this instance an appalling mudslide in the town of Tyrnauz that killed eight people.

In the discourse of contemporary disaster risk management, Lauta and Rytter note, the distinction between natural and man-made has all but disappeared. With regard to Hurricane Katrina, for example, 'scholars focus[ed] on poor levee construction, untimely decision-making, and on structures of social injustice rather than on the category 3 hurricane that made landfall'. Such a perspective, they observe, 'can take the "naturalness" out of any disaster - irrespective of its putative origin'. The Court had lagged behind this emerging consensus on 'the hybridity between man-made and natural hazards' or 'Natech' disasters as they have become known, which experts approach through the 'fundamentally social concepts of vulnerability, resiliency and risk'. In the Budayeva ruling, however, the Court found against Russia on a number of counts - for not having taken adequate steps to prevent the disaster (despite having been forewarned by designated authorities), for not having done enough to inform potential victims of the likelihood of disaster, and for failing to establish a judicial inquiry to investigate the deaths. In response to this development, Lauta and Rytter propose an 'all hazards' approach to the right to life, one that 'concretely assesses the risk profile of the hazard(s) in question, rather than emphasizing the origin', and determines the level of required protection according to three criteria: the foreseeability, gravity and mitigability of the threat. Europe lost 80000 lives to disasters between 2002 and 2014 alone - and climate change is likely to make things worse in coming years; presumably anything that encourages prevention, information and response represents progress.

War, Clausewitz wrote, may borrow its logic from politics, but its grammar is all its own. ${ }^{1}$ Gabriel Blouin Genest and Sylvie Paquerot make a similar claim about human rights in their fascinating disquisition into the relative failings of international human rights law as applied to environmental concerns. Characterizing environmental human rights as a terrain of conflict, Genest and Paquerot suggest the primary function of human rights is to provide a grammar of struggle over public goods rather than a formula for their entrenchment. This, rather than their 'liberal origins' (a popular Marxian interpretation) accounts for the relative 'lack of emancipatory interpretation[s] of human rights' - since, 'contested interpretations ... do not necessarily follow a linear pathway towards emancipation'. 'Rights cannot guarantee in themselves any specific conclusion to a conflict, since their translation by the actors involved is not and will not be - definitive'. The authors characterize human rights as a Bourdieu-esque political field, and, quoting Bourdieu, a 'place, where, within the competition between those involved, political results, problems, programs, analyses concepts, and events are

1. C von Clausewitz, Vom Kreig [On War 1932]. Trans M Howard and P Paret (Berlin, Ullstein 1980) Book VIII, Ch 6, p. 683. 
created, between which ordinary citizens ... must choose'. The point of invoking human rights, then, is to allow for the contestation of oppositions, to 'enable the emergence of political debates beyond the sanitized view of peaceful relationships in society'. This would account for the inherently feisty nature of human rights discourse - the licence to disagree that accompanies human rights debate in any quasi-consensual space. Added to this, the authors apply the concept of 'translation' from Latourian Actor Network Theory. Human rights provide a language of translation between competing views - but translation in this mode, 'presupposes the distortion and altering of information, and not just its dissemination through connections'.

It is for this reason, Genest and Paquerot contend, that human rights struggles so rarely give rise to outcomes that might fulfil their promise. The authors provide an excellent example in the case of water access rights. They perceptively remark that the upshot of the debate within the United Nations' human rights system was that privatization of water 'is not understood to contradict the right to water, whereas, for many actors, the objective had been precisely to use the right as a weapon against privatization and commodification'. If human rights activists lost the war, they may, however, have won the odd battle: '[t]he characterization ... of the conflict ... in terms of human rights, however, obliged States to temper both their sovereignty and submission to market rules in order to establish [their] legitimacy'. Erudite and intelligent, Genest and Paquerot's article nicely finishes the inquiry begun by Baxi: much as the search for 'justice' becomes ever more urgent and inescapable with each new iteration of the climate regime, and as 'nature' royally recolonizes the 'human' - our theories and tools of justice and human rights are only, it seems, as good as the humans who wield them.

Stephen Humphreys

Associate Professor of Law, London School of Economics, UK 